Open Access

\title{
On the inclusion of learners with visual impairment in computing education programs in Brazil: practices of educators and perceptions of visually impaired learners
}

\author{
Leandro Luque ${ }^{1,2^{*}+}$ (1) Leônidas O. Brandão ${ }^{3}$, Elisabeti Kira ${ }^{3}$ and Anarosa A. F. Brandão ${ }^{1 \dagger}$
}

\begin{abstract}
Background: Individuals with visual impairment face varied challenges when attending education programs in many fields and levels. In computing education programs, the frequent required use of charts, graphs, and diagrams poses additional challenges to their inclusion. In order to inform and to establish appropriate action plans for a more inclusive scenario, it is important to gather information from the parties involved. In this context, this work presents the practices of educators and the perceptions of visually impaired learners regarding such inclusion.

Methods: The practice and perceptions were gathered from a survey with 56 computing educators and with 19 visually impaired learners who have attended computing education programs.

Results and discussion: The results suggest educators have limited access to knowledge related to the inclusion of visually impaired learners in lectures and feel unprepared to this scenario. On the other hand, visually impaired learners do not feel included in computing education programs.
\end{abstract}

Keywords: Computing education, Inclusion, Visual impairment, Blind, Perception, Survey

\section{Background}

Blindness and low vision are together the world's second most common impairment, only after hearing loss [1-3]. In Brazil, they are the most common impairment, affecting about $3.5 \%$ of the population [4], which corresponds to 582 thousand blind people and 6 million people with low vision.

As any other person, individuals with visual impairment have the right, as provided by law, to fully participate into society. Article 5 of the Brazilian Federal Constitution (Constituição Federal) [5] states that:

"All individuals are equal, without any kind of distinction, guaranteeing $[. .$.$] the inviolability of the$

\footnotetext{
*Correspondence: leandro.luque@gmail.com

${ }^{\dagger}$ Equal contributors

'Escola Politécnica, University of Sao Paulo, Prof. Luciano Gualberto Av. T3-158, 05508-010 Sao Paulo, SP, Brazil

${ }^{2}$ Sao Paulo State Technological College - Fatec, Carlos Barattino St. 908, 08773-600 Mogi das Cruzes, SP, Brazil

Full list of author information is available at the end of the article
}

right to life, liberty, equality, security, and property [...]" (translated by the authors)

Regarding education, there are various legal instruments that assure people with impairments the right to an inclusive scenario [6-8]. Among these, the administrative ordinance (Portaria) no. 1679 [6] defines the requirements for accessibility in higher education and the Statute of People with Disabilities (Lei Brasileira de Inclusão da Pessoa com Deficiencia) [7] highlights the right to an inclusive education at all levels, as quoted next.

"Education is a right of individuals with impairments that must be secured at all educational levels [...], in order to achieve the maximum possible development of their talents and their physical, sensory, intellectual, and social skills, according to their characteristics, interests and learning needs [...]. It is a public authority incumbency to ensure, create, develop, implement, encourage, monitor and evaluate: [...] XIII - Access to higher and technological education in equal 
opportunities and conditions [...]" (translated by the authors)

Unfortunately, the scenario as provided by law does not correspond to reality. Courses in many educational levels and fields of knowledge are still inaccessible to visually impaired learners [9-13] due to institutions' internal and external factors.

When considering higher education, the main external factors that influence learner enrollment are related to selection exam accessibility, quality of lower education levels, and transportation accessibility. In Brazil, candidates to higher education must be approved in a selection exam [14]. To give equal conditions in such exams to individuals with visual impairment, the selection exam must be accessible. In addition, the education at lower levels must have been effective so that the candidate has equal conditions to compete. Transportation accessibility is important not only prior to learner enrollment, but during the whole course period. Internal factors include the lack of accessibility in the physical environment, educational material, pedagogical methods, cultural aspects such as prejudice, among others.

Amiralian [15] and Mrech [16] consider two pedagogical conceptions to the inclusion of learners with impairments in education programs. The first conception, called normalization, is aimed at making learners with impairments similar to other classmates. In this conception, the educator is not generally supported by an expert in special education. Learners with impairments have to show their ability to attend regular classes. The other conception seeks to understand how they are constituted and perceive the world in order to adapt material and pedagogical methods. This conception does not seek to normalize them or to impose concepts, standards, and values of sighted people.

Several studies have shown that inclusive education is more beneficial than segregated education for all students [17-20]. These surveys, focused on K12 education, show that both learners with impairments and sighted learners gain from this coexistence, and there are no records of any adverse effects on learning or socialization processes. Adverse effects, however, are noticeable when learners with impairments are simply enrolled and attend regular programs, without an environment that welcomes and values differences.

In this work, we consider that the same is true in higher education and our focus of interest is related to computing education programs.

\section{Inclusion of visually impaired learners in the computing field}

In computing education programs, the frequent required use of charts, graphs, and diagrams creates additional obstacles to visually impaired learners. Some examples of graphical notations and disciplines that use them are (i) BPMN-business process model and notation, MSD - module structure diagram, DFD—data flow diagram, MHD-module hierarchy diagram, IDEFintegrated DEFinition methods, SysML-systems modeling language, and UML-unified modeling language (Software Engineering); (ii) flowcharts (Software Engineering, Algorithms, and Data Structures, and Programming Language); (iii) graphs and their subtypes, such as trees (Algorithms and Data Structures, Analysis of Algorithms, Graph Theory, Artificial Intelligence, Performance Analysis, Compilers, Formal Languages, Software Testing, and Automata and Computability); (iv) Petri nets (Distributed Systems); and (v) ERD-entity-relationship diagram (Database and Software Engineering)

Educators use such graphical representations to teach and to exemplify concepts [21], and visually impaired learners are sometimes not allowed to express their knowledge through alternative tasks [22]. In order to convey information in graphical representations to visually impaired learners in classroom activities, educators would have to receive support from assistants or use low-/hightech assistive technologies [23]. Examples of low-tech assistive technologies are tools such as pens or tactile drawings [24] and physical objects with specific semantics $[25,26]$. Examples of high-tech assistive technologies are tactile displays [27], optical character recognition (OCR) [28], screen readers [29], among others.

In addition to the accessibility of graphical content, the accessibility of software systems used in computing education programs, such as IDE-integrated development environment and CASE-computer-aided software engineering, is also important to make inclusion possible.

Over the last 20 years, many studies on the inclusion of visually impaired learners in the computing field have been published. Some of them reported experiences related to teaching computing topics, such as objectorientation, graphs, and the UML, to visually impaired learners [21, 25, 30-33]. Other studies focused on haptic and multimodal interaction with computing diagrams for individuals with visual impairment [34-39]. Yet, other studies covered textual and audio-based interfaces to convey the content of computing diagrams to individuals with visual impairment [40-47]. These studies considered both linear and hierarchical access to diagram content. Finally, other studies covered collaborative diagram-based activities involving individuals with visual impairment [48-52].

Despite the extensive research on the subject, further research and technological development effort are required to produce a more inclusive scenario [51, 53]. An important step toward such inclusive scenario is to gather information from the parties involved. This information is 
required to establish appropriate action plans by institutions, educators, and decision makers.

Considering this context and the absence of such information for computing education in Brazil, this work presents the results of a survey with visually impaired learners and educators in computing education programs. This survey was conducted to gather information about the practice and perceptions of learners regarding their inclusion and of educators when visually impaired learners attend their lectures.

In the "Discussion" section, we talk about some alternatives to promote a more inclusive scenario. In addition, we believe the information present in this paper may guide and support the definition of procedures and policies to promote a more inclusive scenario.

\section{Methods}

We conducted a survey using questionnaires aimed at identifying the practice and perceptions of educators and visually impaired learners regarding their inclusion in computing education programs. Particularly, we aimed at gathering information about the following aspects:

- Institutional provision for educators and learners;

- Changes in didactic methods (lecture style, accessibility of graphical representations, assessment, and group activities); and

- Perception of changes in didactic methods.

The research was carried out by sending electronic questionnaires, with multiple choice and short answer questions, targetting two distinct groups: (i) educators in the field who have taught visually impaired learners and (ii) visually impaired learners who have attended courses in the field. The questionnaires for educators and learners may be found at https://github.com/leluque/jbcs.

Educators were contacted through the Brazilian Computer Society (SBC) general list [54]. An invitation e-mail was sent to everyone in the list. The list has about 7650 members, which comprises professionals, educators, and students in the computing field. There is no available data regarding the number of educators in the list. Visually impaired learners, on the other hand, were contacted through the Blind Programmers list [55], which has individuals with visual impairment working in the computing field. An invitation e-mail was sent to everyone in the list. The list has about 180 individuals with visual impairment that are in the computing field.

The questionnaire for educators was created using Google Docs forms [56], and SurveyMonkey [57] was used for learners considering the lack of accessibility of the former to individuals with visual impairment [58]. SurveyMonkey advertises its compliance with Section 508 [59] and WCAG 2 [60, 61]. In addition, other studies in the literature use SurveyMonkey to apply questionnaires to individuals with visual impairment $[62,63]$. Finally, we had already assessed the SurveyMonkey accessibility in previous surveys.

The questionnaires were released to receive responses from June 12 to October 16, 2015. The responses were analyzed through descriptive statistics-generation of contingency tables and calculation of percentages.

\section{Results: educators' practices and visually impaired learners' perceptions}

In this section, we present the results of the survey. First, we present the results for the questionnaire filled in by educators. Then, in the second subsection, we present the results for the questionnaire filled in by learners.

\section{Results for educators}

The questionnaire received 56 responses. All respondents have had experience of teaching computer science subjects to visually impaired learners.

\section{Institutional provision}

Regarding institutional provision, we asked educators if they had received any kind of information or training from the institution to teach visually impaired learners.

From the 56 respondents, only 12, which corresponds to $21 \%$, declared to have received institutional provision in terms of training or information. The majority of educators, 44 , which corresponds to $79 \%$, declared not having received such provision.

Among the educators' comments regarding institutional provision, we can quote:

"Teaching students with visual impairment was a challenge for me. I have not received instructions (...) and I had to (handle the situation all by myself)."

"It was an interesting experience dealing with this situation. I could see how unprepared we are to receive students with any kind of difficulty. Anyway, my adaptation to the new situation was quick and I believe for other educators as well, but it is necessary to rethink the teaching strategies to improve inclusion."

"[...] I understand that many educators feel unprepared to carry out the task of teaching students with visual impairment. Teaching professionals need to receive training and to develop the skills required to teach students with special needs."

\section{Learner assessment and group work}

Regarding learner assessment and group work, we asked educators if they have involved visually impaired learners in group activities and assessed them differently. 
Out of 56 educators, the majority, 47, which corresponds to $84 \%$, declared to have involved visually impaired learners in group activities with other learners. The other 9 educators declared not to have involved such learners in group activities.

Regarding learner assessment, out of 56 educators, 27, which corresponds to $48 \%$, declared to have assessed visually impaired learners differently from sighted learners. The other 29 educators declared not to have assessed them differently.

\section{Lecture style and educational material}

From the 56 educators, 47, which corresponds to $84 \%$, have used the blackboard in their lectures. Since visually impaired learners cannot access the blackboard content, we asked educators if they have changed the lecture style when teaching visually impaired learners. From these 47 educators, 6 did not change anything in their lectures when teaching visually impaired learners. Among the 41 educators who have changed the lecture style, we identified five strategies they used. These strategies are listed next.

- Using a specific part of the blackboard (for learners with low vision);

- Changing font size (use of larger fonts);

- Delivering accessible material after the lecture;

- Delivering accessible material prior to the lecture; and

- Changing verbalization-repetitively verbalized the blackboard content;

Figure 1 presents the frequency of use of each strategy (individually and combined).

The most common strategy used by educators was delivering material prior to the lecture. This was the only strategy used by 30 educators. Changes in verbalization

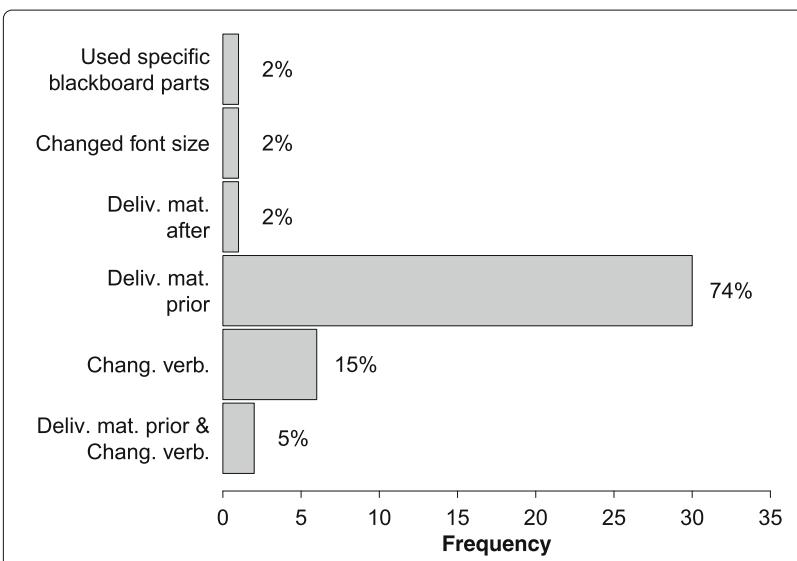

Fig. 1 Strategy usage frequency. The figure presents the frequency of use of each strategy individually and in combination by 41 educators who kept using blackboards in their lectures was the only strategy used by 6 educators. Two (2) other educators combined delivering material prior to the lecture with changes in verbalization. Other strategies were mentioned only once.

\section{Approaches to make graphical representations accessible}

From the 56 educators, 40, which corresponds to $71 \%$, taught subjects that involved the use of graphical representations. For those who use graphical representations, we inquired about the approaches used to make graphical representations accessible to visually impaired learners. From these 40 educators, 3 answered they did not know any approach to make graphical representations accessible to visually impaired learners. Among the remaining 37 educators that knew some approach, 2 did not use any. The remaining 35 educators mentioned six different approaches they used. These approaches can be classified according to the sensory perception they are based on (hearing, touch, and sight), as described next.

The approaches based on hearing comprise (i) textual description, in which a textual description of the graphical content was provided to learners prior to the lecture-the textual description was synthesized by screen readers; (ii) verbal description, in which the graphical representation content was read aloud by the educator during the lecture; and (iii) assistant support, in which the graphical representation content was read aloud by an assistant during the lecture.

Regarding touch, the following approaches were used: (iv) physical objects, in which physical objects were used to represent the graphical representation content and (v) tactile representations in paper, in which raised representations, both printed and created with special pens, were used to represent the graphical representation content. Some educators also used Braille to represent textual elements of the graphical representation.

For learners with low vision, amplification (sight) was used to make the access feasible to the graphical representation in its original representation.

The most used sense, individually and in combination, was hearing (Fig. 2). Verbal description, assistant support, or textual description (read by screen readers) was mentioned by 35 respondents that used some approach. Among these, textual description was the most widely used approach, mentioned by 30 educators (85\% of the educators that used some approach). In most cases, 17, textual description was used alone. Touch-based approaches were used individually by 3 educators (9\%) and in combination with hearing by 12 educators (34\%). Among these, tactile representations were mentioned by 10 out of 35 (29\%) respondents. Sight-based approaches were mentioned by only 2 educators. 


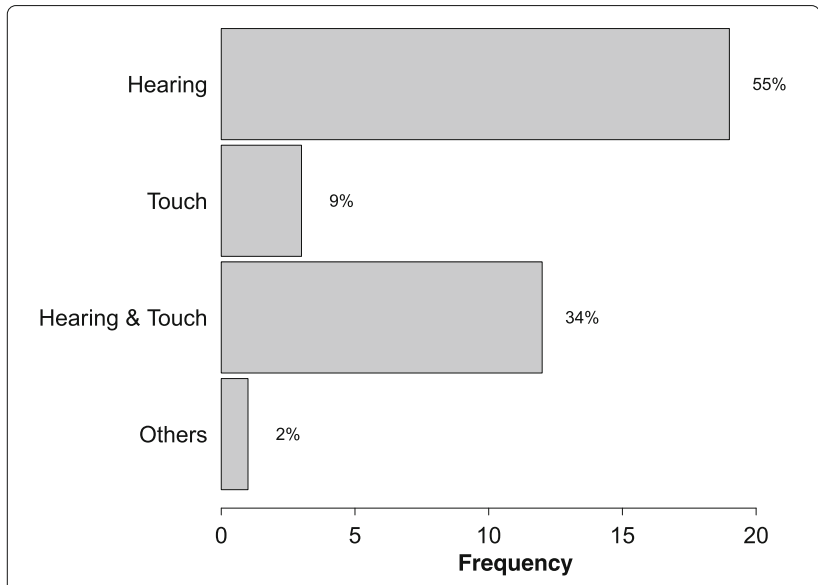

Fig. 2 Frequency of use of each approach. The figure presents the frequency of use of each approach used by 35 educators to accessibilize graphical representations

\section{Influence of institutional provision in other aspects}

In order to investigate if institutional provision may influence inclusion in group activities, appropriate assessment, change in lecture style over the blackboard, and accessibility of graphical representation, we constructed contingency tables (Tables 1, 2, 3, and 4).

As shown in Table 1, from those educators who had institutional provision, 10 out of 12 (83\%) involved visually impaired learners in group activities. For those who not had institutional provision, 37 out of 44 (84\%) involved such learners in group activities. Such small difference indicates that it is not possible to perceive a statistical relation between institutional provision and the inclusion of visually impaired learners in group activities.

With respect to assessing visually impaired learners (Table 2), about $50 \%$ of the educators, with or without institutional support, declared to use different assessment strategies.

Therefore, by Tables 1 and 2, the institutional provision does not have influence over the educator with respect to including visually impaired learners in group activities and to assessing them differently.

However, institutional provision seems to influence the classroom dynamics in terms of changing lecture style over blackboard and making graphical representations accessible. In fact, all educators with institutional

Table 1 Contingency table of institutional provision by including learners in group activities

\begin{tabular}{lllll}
\hline & & \multicolumn{2}{l}{ Involved in group activities } & \\
\cline { 3 - 4 } & & No & Yes & 44 \\
\hline Institutional & No & 7 & 37 & 12 \\
Provision & Yes & 2 & 10 & 56 \\
& & 9 & 47 &
\end{tabular}

Table 2 Contingency table of institutional provision by use of different assessment strategies for visually impaired learners

\begin{tabular}{lllll}
\hline & & \multicolumn{2}{l}{ Assessed learners differently } & \\
\cline { 2 - 4 } & & No & Yes & 44 \\
Institutional & No & 22 & 22 & 12 \\
Provision & Yes & 7 & 5 & 56 \\
& 29 & 27 & \\
\hline
\end{tabular}

provision declared to have made these changes, as shown in Tables 3 and 4. In contrast, from those educators who had not had institutional provision, $84 \%$ declared to have made these changes.

\section{Results for learners}

In this subsection, we present the results for the questionnaire filled in by learners.

There were 31 respondents to the visually impaired learner's questionnaire, of whom 19 were considered valid. We considered invalid those responses that were incomplete and contained only information about the learner's degree of visual impairment.

The respondents include 7 learners that are currently attending a computing education program, corresponding to $37 \%$ of all respondents, and 12 learners that previously attended a program in the field, corresponding to $63 \%$. From those that have already attended a program in the field, only one did not complete the program.

Regarding their degree of visual impairment, 16 learners (84\%) declared to be completely blind and 3 (16\%) as having low vision.

About $50 \%$ of the learners have more than 12 years of experience using computers and 1 year as professionals in the field. All of them have at least 5 years of experience as users. The most experient user has been using computers for 16 years.

\section{Educational level and institutions}

When considering the educational level they attended, 14 , corresponding to $74 \%$, attended higher education programs. The other 5, corresponding to $26 \%$, attended certification (known as "technical" in Brazil) or professionalizing programs.

Table 3 Contingency table of institutional provision by using some strategies to make graphical representations accessible

\begin{tabular}{lllll}
\hline & & \multicolumn{2}{l}{ Made graphical representations accessible } & \\
\cline { 2 - 4 } & & No & Yes & 29 \\
Institutional & No & 5 & 24 & 11 \\
Provision & Yes & 0 & 11 & 40 \\
& & 5 & 35 &
\end{tabular}


Table 4 Contingency table of institutional provision by changes in lecture style for educators that have used the blackboard

\begin{tabular}{lllll}
\hline & & \multicolumn{2}{l}{ Changed lecture style over blackboard } & \\
\cline { 3 - 4 } & & No & Yes & 39 \\
Institutional & No & 6 & 33 & 8 \\
Provision & Yes & 0 & 8 & 47 \\
& & 6 & 41 & \\
\hline
\end{tabular}

Higher education institutions in five different states were attended by learners: (i) MT-Mato Grosso: UNIVAG-Várzea Grande University Center; (ii) PRParaná: UNICESUMAR-Maringa University Center and UTFPR - Federal University of Technology of Parana; (iii) RS-Rio Grande do Sul: UCS-University of Caixas do Sul; (iv) RJ-Rio de Janeiro: Estácio de Sá University; and (v) SP-Sao Paulo: Anhanguera Faculty, Impacta Faculty, SENAC, UNICAMP-University of Campinas, UNICID-University of the City of Sao Paulo, UNIPPaulista University, and USP-University of Sao Paulo. This group includes two of the best Brazilian universities considering international rankings [64].

\section{Difficulties due to visual impairment}

The learners were asked if they faced any difficulty due to their impairment in the courses. Only one of them answered he/she did not face any difficulty due to the impairment. This learner is completely blind and attended a short professionalizing course in a non-regular educational institution. All learners in universities and certification institutions reported difficulties.

One learner highlighted the lack of institutional provison in terms of infrastructure and assistance.

"(I felt a) lack of proper (institutional) support ... They provided the minimum ... I ... filled in the questionnaire about disabilities ..., asking (for) a(n) (assistant) to help me in the classroom, so that I could (have a better interaction) ..., but I did not receive any support. (The results of the education process) depended mainly on the good will of the (educators). There were no tactile floors and means to locate myself ..."

In addition to the lack of institutional provision, another learner highlighted a lack of educator's knowledge about the peculiarities of visual impairment.

“(I noticed a) ... lack of (educators) knowledge about the peculiarities of visual impairment. For example, the educators have an ingrained habit of pointing the items in the slides without mentioning their names or giving more details about the layout of the content.

(Additionally, there were) laboratories with computers without screen readers and EAD platforms (that did not meet) the minimum accessibility requirements."

\section{Accessible books and assistant support}

The learners were asked about the availability of accessible books and of assistant support during the program. They had to answer using a Likert scale, from Strongly Disagree (1) to Strongly Agree (5), the following statements: "All books in my course syllabus were accessible" and "I have had assistant support in all lectures in my course."

Figures 3 and 4 present their responses. Out of 19 learners, 2 did not answer these questions. Among the 17 respondents, 4 learners, corresponding to $24 \%$, reported to have had access to accessible versions of all the books used in the program or to assistant support in all lectures. In fact, 3 of them answered "Strongly Agree" to both questions. Two others chose this answer to only one of the questions. On the other hand, 5 learners, corresponding to $29 \%$ of the respondents, reported to have had no access to accessible versions of all the books used in the program.

Regarding assistant support, 4 learners, which corresponds to $24 \%$, reported not to have had access to assistant support in all lectures. Other 4 learners reported to have had access to assistant support in all lectures.

\section{Approaches educators used to make graphical representations accessible}

We asked learners about the approaches their educators used to make graphical representations accessible. Among the 19 learners, 5 of them did not answer the question. Among the 14 who responded, 5, corresponding to $36 \%$, answered that no approach was used, so that they did not have access to any graphical representation. The other 9 respondents mentioned five different strategies used by educators. As for educators, these

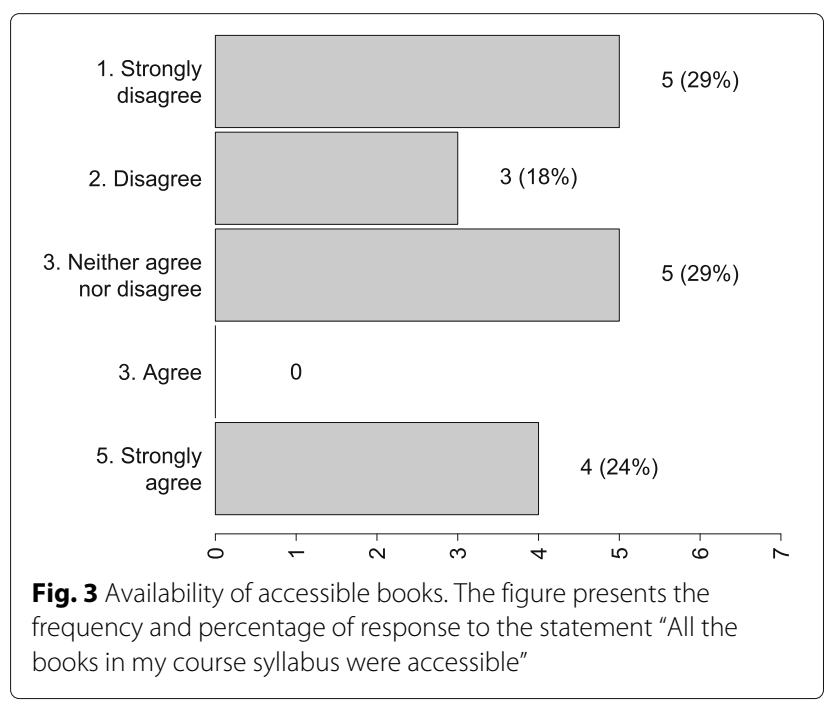




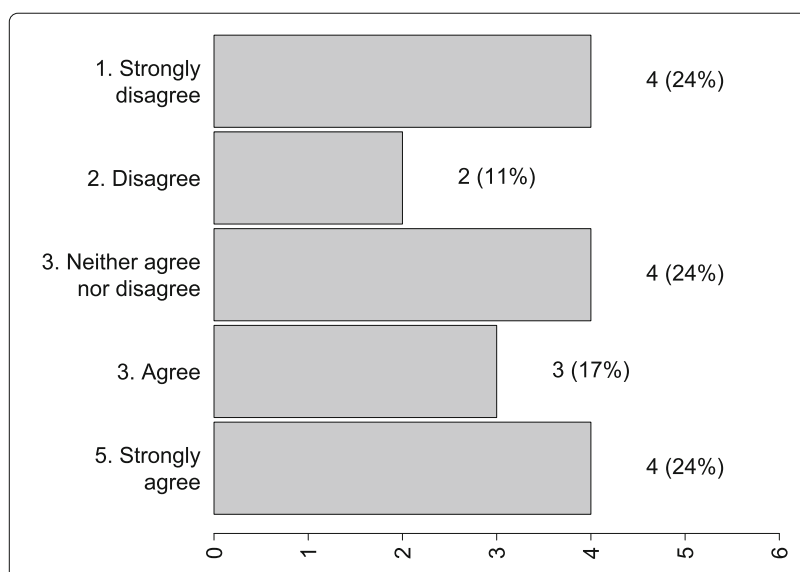

Fig. 4 Availability of assistant support. The figure presents the frequency and percentage of responses to the statement "I have had assistant support in all the lectures in my course"

strategies can be grouped by sensory perception. Hearingbased approaches comprise textual and verbal description. Touch-based approaches comprise multiplan, tactile drawings, and Braille impressions.

In Fig. 5, we present the frequency of response. The most widely used sense was touch. It was used individually by $4(29 \%)$ educators and in combination with hearing by $3(21 \%)$ educators. Among the touch-based approaches, tactile drawings was the most often mentioned.

\section{Collaboration with classmates related to graphical representations}

Regarding collaboration among visually impaired learners and classmates in lectures that involved the use of graphical representations, 4 learners did not answer

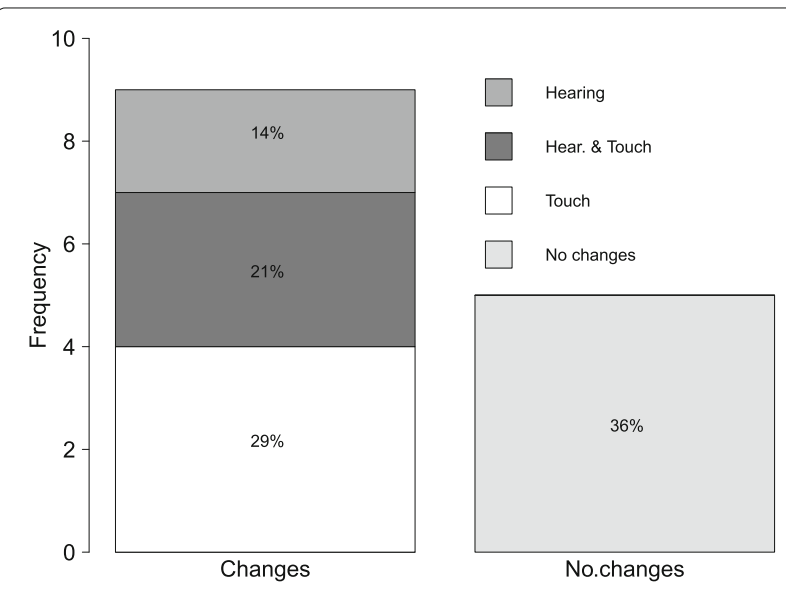

Fig. 5 Sense usage frequency. The figure presents the frequency of approaches by sensory perception their educators used to make graphical representations accessible the question. From the 15 respondents, 7, which correspond to $47 \%$, reported they were not involved in group activities and did not interact with classmates, and 8 reported to use textual descriptions, tactile representations, or counted on classmate support, as shown in Fig. 6. The most widely used approach was textual and verbal description together, answered by 5 respondents, which correspond to $33 \%$ of all question respondents. Classmate help was used by 2 learners and tactile drawing by 1 learner.

\section{Assessment}

The learners were also asked about the way they were assessed in subjects that involved the use of graphical representations. As 4 learners did not answer this question, we present the results for 15 respondents in Fig. 7 .

Among the 15, 6(40\%) were assessed regarding their conceptual knowledge about the subject. Other 5 respondents, which correspond to $33 \%$ answered they were not assessed at all. Classmate/assistant help was answered by 2 respondents. Finally, oral assessment and tactile drawings were mentioned by 1 learner each.

\section{Problematic topics}

We asked visually impaired learners about the topics they consider the most challenging in the courses they have taken. The following topics were mentioned by learners: (i) Applied Math; (ii) Analytical Geometry; (iii) Linear Algebra; (iv) Discrete Math; (v) Computer Graphics; (vi) Physics; (vii) Formal Languages; (viii) Automata and Computability; (ix) Software Engineering; (x) Database; (xi) Web Technology; (xii) Calculus; (xiii) Mobile Programming; (xiv) Computer Networks; (xv)

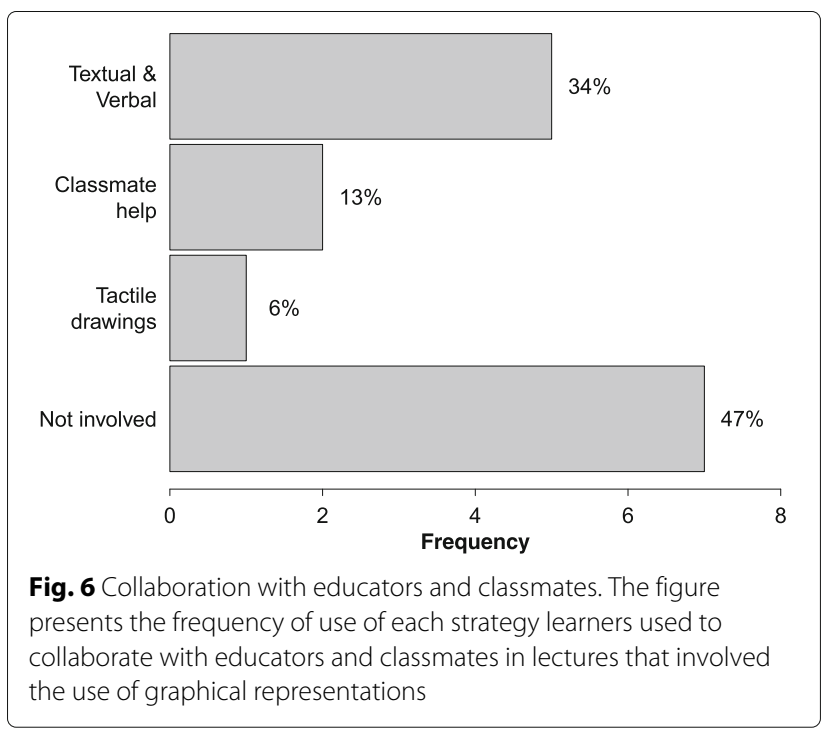




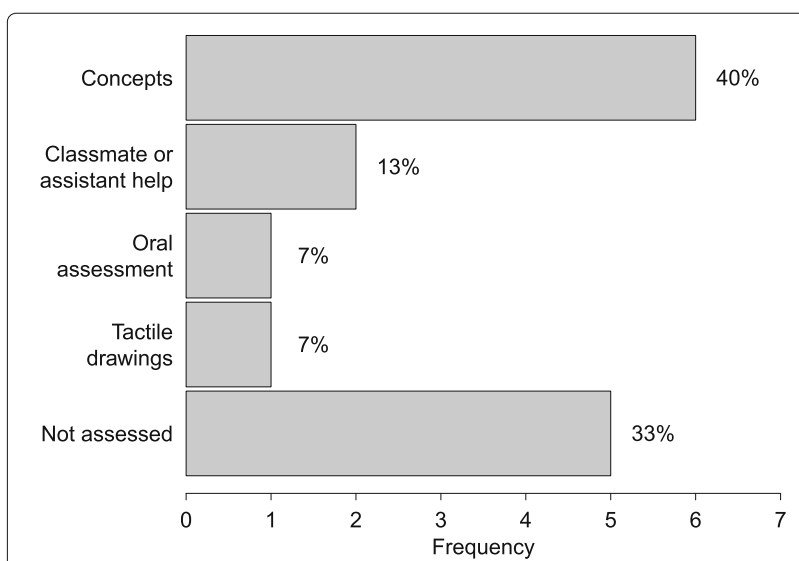

Fig. 7 Graphical representations and learner assessment. The figure presents the strategies used to assess learners in subjects that involved the use of graphical representations

Digital Circuits; (xvi) Algorithms; and (xvii) Visual Programming Languages.

The number of subjects mentioned by learners comprises a significant part of computing education programs. In courses such as Computer Science and Computing Engineering, learners mentioned theoretical topics that form the foundation of the field (e.g., Discrete Math, Formal Languages, and Automata and Computability). In courses such as Information Systems and Systems Analysis and Development, central disciplines (Software Engineering, Database, Web Technology, Visual Programming Languages, and Mobile Programming) were mentioned by learners. This amplitude of challenges reinforces the necessity of further research and technological development effort.

\section{Discussion}

In the following subsections, we discuss the aforementioned results.

\section{Result contextualization}

The results we present are related to institutions in five different Brazilian states: (i) MT-Mato Grosso, (ii) PRParaná, (iii) RS-Rio Grande do Sul, (iv) RJ-Rio de Janeiro, and (v) SP-Sao Paulo. While one must analyze the results considering its spatial contextualization, the aforementioned five states contain about $48 \%$ of the main computing-related undergraduate courses in Brazil (Computer Science, Computer Engineering, Information Systems, and System Analysis and Development) [65]. Furthermore, 9 of the 15 best Brazilian educational institutions according to the Times Higher Education [66] are located in these states and we gathered data about 2 of them. In addition, they include four of the five most rich Brazilian states, considering their gross domestic products [67]. Considering that, it is expected that the inclusion scenario in these institutions represent part of the best scenario in educational institutions in Brazil.

\section{Class style and material}

It is well known that blackboard content is not accessible to visually impaired learners. Most educators used blackboards in their lectures. The most widely used strategy by educators to deliver material to learners is "delivery of material prior to lecture," and despite being useful to allow visually impaired learners to follow explanations, this may result in inflexibility in the class content, which can harm the teaching and learning process.

This inflexibility may prevent free interactions between learners and educators, negatively influencing the educational processes. Also, it may increase the sense of distance between participants [51]. For instance, content and examples based on situations raised in class, which could increase the learner's motivation, can hardly be applied in such an inclusive scenario.

Approaches that could be adopted to keep the blackboard lecture style, without creating inflexibility would be:

- Use of smartboards: some smartboards have integrated OCR and its content can be accessed in real-time. Despite being an interesting approach, it can be expensive;

- Use of multimedia projector real-time collaborative text editors: instead of using the blackboard, educators can project documents and share them with learners using real-time collaborative text editors. The visually impaired learners would be able to access the content of the virtual "blackboard" in real time during the lecture.

Despite being useful for textual content, these approaches are not useful to graphical content, as discussed next.

\section{Accessibility of graphical representations}

According to the learners surveyed, the main challenge they faced was when graphical representations were used to convey and to discuss concepts.

These graphical representations often take the form of graphs (nodes and edges) but have peculiarities that result in complex graphical notations. Examples of this complexity include the UML class diagram and ERD, in which the inherent complexity of a node is often greater than that resulting from its connections, an unusual property for graphs. 
These representations are inaccessible to visually impaired learners in their original format; they represent concepts and knowledge that can be conveyed to learners in different formats. The two most widely used approaches, both by educators and learners, were converting them to textual and tactile representations. While textual representations may consider only concepts, tactile representations often take into account graphical aspects. We have not found any empirical study that compares the effectivity of these approaches with experiments. Without this information, we could consider the usage of tactile maps as a normalization pedagogical tool, since it tries to just allow visually impaired learners to access graphical representations the same way sighted learners do. In other words, it does not take into account the mental model visually impaired learners create when interacting with graphical representations and how it could be represented in order to maximize their performance.

Regarding tools to make these representations accessible in real-time collaborative activities, such as in a classroom, there have been some recent researches that have delivered tools to support collaborative interaction between people with visual impairment and sighted people with graphical representations, some of them in real time. Model2gether [52], CCmi [68], and [48] are examples of these tools.

Another aspect that represents a great challenge to inclusion, as cited by learners, is the availability of accessible books, as discussed next.

\section{Accessible books}

Without being able to access the same material available to sighted learners, it is not possible to offer equal learning conditions to visually impaired learners. The students' answers indicate that, in most cases, only part of the official bibliography was made available in an accessible format.

Some approaches can contribute to changing this scenario. To understand these approaches, it is worth noting that many books, in different fields, do not have equivalent digital editions. This is the case of books published before the emergence of the digital book market.

To make already published non-digital material accessible to visually impaired learners, universities could have departments responsible for making material accessible. This is the case in many universities [69-71]. Using current high-speed scanning and quality OCR techniques, this is not as difficult as it used to be. This could also be a government initiative. The Brazilian government took this initiative regarding books used at lower education levels [72]. A partnership with representative societies of each field could result in a joint effort, which could be shared by public and private institutions, to produce a better result than each institution by itself. The most recent law related to the inclusion of individuals with impairment in society [7] does not require the existence of specialized departments with the aforementioned role.

For new books, a legislation to guarantee the publication of accessible editions of every published book would ensure accessible material for the future, since publishers have electronic versions of their books. While the article 68 of the Statute of People with Disabilities (Lei Brasileira de Inclusão da Pessoa com Deficiência) [7] specifies that the government must adopt mechanisms to promote the production, edition, and distribution of accessible books, it is still not mandatory in Brazil the publication of digital versions for new books.

\section{Institution training}

The lack of training was a concern for most educators, who do not have access to knowledge related to the inclusion of people with visual impairment in lectures. The inclusion in such cases depends only on the educator's initiative to search for approaches and tools that can help them during the process. It is more aligned with the normalization conception aforementioned. In some cases, the educator does not change his/her lecture style and just counts on the help of volunteer sighted learners or assistants to "translate" what is being said into an accessible format. Again, the existence of departments specialized in accessibility in universities could contribute with training programs to educators. Furthermore, the inclusion of accessibility-related content in graduate courses to educators could also contribute to change the existing scenario.

There are some initiatives to offer courses related to accessibility that can be used by educators to compensate the lack of institution training. The University of Brasilia offers an open online course on accessible materials for the Moodle that can be accessed at https://moodle.ead. unb.br. Another initiative, by the UNICAMP-University of Campinas, is dedicated to specialized educational service educators, but it is only available to invited users, at http://tnr.nied.unicamp.br/.

\section{Base of knowledge to inclusion}

An initiative that could contribute to changing the inclusion scenario in Brazil is establishing an electronic base of knowledge, with scientific articles and tools, related to the inclusion of visually impaired learners in computing education programs. The USA, as an example, has a project funded by the government and maintained by the University of Washington, called Access Computing [73]. It is a collection of resources to include learners with impairments in the computing field.

Currently, any Brazilian educator, who wishes to include visually impaired learners in his/her class, has to conduct his/her own research to identify possible approaches to 
make this inclusion possible. If a central repository with such information were available, this could contribute to changing in this scenario.

\section{Conclusions}

This work presented the results of surveys conducted with visually impaired learners and educators in computing education programs.

In addition to educators and visually impaired learners, institutions and sighted students that take part in the inclusion process are important as well. This research does not present data related to these parties. While educational institutions could be surveyed, we understand that information gathered by educators and learners is more faithful, since institutions are obliged to offer minimal conditions to learners with impairments and admit the absence of these conditions could cause problems to the institutions. Regarding sighted students, there is no group or specific mean to find them. One approach to gather data about sighted students is to follow them during a course in which they have a classmate with visual impairment.

In our view, it is important to collect information about the inclusion of visually impaired learners in computing education programs to establish appropriate action plans by institutions, educators, and decision makers. We consider this work relevant in this context because the type of information present herein may guide and support the definition of procedures and policies to promote a more inclusive scenario.

Despite any effort by educators and institutions to promote a more inclusive scenario, most learners do not feel included at all.

The results indicate that further research and technological development efforts are required to produce a more inclusive scenario. A method to guide institutions, educators, and learners in this scenario would be of great contribution to the field. We discussed some alternatives that could be adopted to produce this inclusive scenario.

\section{Abbreviations \\ BPMN: Business process model and notation; CASE: Computer-aided software engineering; DFD: Data flow diagram; IDE: Integrated development environment; IDEF: Integrated definition methods; MER: Entity-relationship diagram; MHD: Module hierarchy diagram; MSD: Module structure diagram; MT: Mato Grosso State; OCR: Optical character recognition; PR: Paraná State; RJ: Rio de Janeiro State; RS: Rio Grande do Sul State; SBC: Brazilian Computer Society; SP: Sao Paulo State; SysML: Systems modeling language; UCS: University of Caixas do Sul; UML: Unified modeling language; UNICAMP: University of Campinas; UNICESUMAR: Maringa University Center; UNICID: University of the City of Sao Paulo; UNIP: Paulista University; UNIVAG: Várzea Grande University Center; USP: University of Sao Paulo; UTFPR: Federal University of Technology of Parana}

\section{Funding}

This work received funding from the TOSHIBA Scholarship Program via the Escola Politécnica, University of Sao Paulo, grant 2014/Dr-02 (TOSHIBAEPUSP). It was also supported by Google, Research Awards for Latin America (LATAM).

\section{Authors' contributions}

$\mathrm{LL}$ and AAFB designed and conducted the survey and wrote the text. LOB and EK reviewed the survey questionnaires, helped with the statistical analysis, and contributed to the final version of the text. All authors read and approved the final manuscript.

\section{Ethics approval and consent to participate}

The method used in this work was approved by the USP University Hospital Research Ethics Committee (CAAE 49264815.3.0000.0076).

\section{Competing interests}

The authors declare that they have no competing interests.

\section{Publisher's Note}

Springer Nature remains neutral with regard to jurisdictional claims in published maps and institutional affiliations.

\section{Author details}

${ }^{1}$ Escola Politécnica, University of Sao Paulo, Prof. Luciano Gualberto Av. T3-158, 05508-010 Sao Paulo, SP, Brazil. ${ }^{2}$ Sao Paulo State Technological College - Fatec, Carlos Barattino St. 908, 08773-600 Mogi das Cruzes, SP, Brazil. ${ }^{3}$ The Institute of Mathematics and Statistics, University of Sao Paulo, Matao St. 1010, 05508-090 Sao Paulo, SP, Brazil.

Received: 1 April 2017 Accepted: 19 January 2018

Published online: 01 February 2018

\section{References}

1. Grue J, Johannessen LEF, Rasmussen EF (2015) Prestige rankings of chronic diseases and disabilities: a survey among professionals in the disability field. Soc Sci Med 124:180-186

2. World Health Organization (2014) Visual impairment and blindness: fact sheet. Technical Report FS282. Accessed 16 Jan 2018

3. World Health Organization (2015) Deafness and hearing loss: fact sheet. Technical Report FS300. Accessed 16 Jan 2018

4. Brazil Cartilha do Censo 2010 - pessoas com deficiência [In Portuguese]. http://www.pessoacomdeficiencia.gov.br/app/sites/default/files/ publicacoes/cartilha-censo-2010-pessoas-com-deficienciareduzido.pdf. Accessed 16 Jan 2018

5. Brazil Constituição da República Federativa do Brasil de 1988 [In Portuguese]. www.planalto.gov.br/ccivil_03/constituicao/constituicao. htm. Accessed 16 Jan 2018

6. Brazil Portaria 1.679 de 2 de dezembro de 1999 [In Portuguese]. http:// portal.mec.gov.br/sesu/arquivos/pdf/c1_1679.pdf. Accessed 16 Jan 2018

7. Brazil Lei 13.146 de 6 de julho 2015 - Estatuto das Pessoas com Deficiência [In Portuguese]. www.planalto.gov.br/ccivil_03/_ato20152018/2015/lei//13146.htm. Accessed 16 Jan 2018

8. Brazil Lei 9.394, de 20 de dezembro de 1996 - Lei de Diretrizes e Bases da Educação Nacional (LDB). www.planalto.gov.br/ccivil_03/leis/L9394.htm. Accessed 16 Jan 2018

9. Albino IB (2010) Acesso e permanência na Universidade Federal do Rio Grande do Norte sob o ponto de vista do docente e do estudante com deficiência [In Portuguese], Master's thesis, Universidade Federal do Rio Grande do Norte, Natal

10. Chahini THC (2005) Os desafios do acesso e da permanência de pessoas com necessidades especiais nas instituições de educação superior de São Luís [In Portuguese]. Master's thesis, Universidade Federal do Maranhão, São Luís

11. Cruz RL (2012) Inclusão no ensino superior: um estudo das representações sociais dos acadêmicos com deficiência visual da UFPB [In Portuguese]. Master's thesis, Universidade Federal da Paraíba, João Pessoa

12. Guerreiro EMBR, Almeida MA, da Silva Filho JH (2014) Avaliação da satisfação do aluno com deficiência no ensino superior [In Portuguese]. Avaliação: Revista da Avaliação da Educação Superior 19(1):31-60

13. Negry KC (2012) Situação de deficiência: a realidade de instituições de ensino superior do Distrito Federal à luz do atendimento prestado aos jovens estudantes com deficiência visual (cegos) [In Portuguese]. Master's thesis, Universidade Católica de Brasília, Brasília

14. Franco MAC (2013) Acesso à universidade: uma questão política e um problema metodológico [In Portuguese]. Educação e Seleção (12):9-26 
15. Amiralian MLTM (2002) O psicólogo e as pessoas com deficiência visual [In Portuguese]. In: Masini EFS (ed). Do Sentido, Pelos Sentidos, Para O Sentido: Sentidos Das Pessoas Com Deficiência Sensorial. Vetor Editora Pedagógica, São Paulo. pp 201-208

16. Mrech LM (1998) O que é educação inclusiva [In Portuguese]. Revista Integração 10(20):37-40

17. Wang M (1997) Atendendo alunos com necessidades especiais: equidade e acesso [In Portuguese]. In: Ainscow M, Porter G, Wang M (eds). Caminhos Para as Escolas Inclusivas. Instituto de Inovação Educacional, Lisboa. pp 49-67

18. Odom SL, Deklyen M, Jenkins JR (1984) Integrating handicapped and nonhandicapped preschoolers: developmental impact on nonhandicapped children. Except Child 51(1):41-48

19. Pastells AA (1993) La integración de alumnos deficientes en la escuela ordinaria [In Spanish]. Revista de Educación Especial, Barcelona (12):44-57

20. Sekkel MC (2003) A construção de um ambiente inclusivo na educação infantil: relato e reflexão sobre uma experiência [In Portuguese]. Phd thesis, Universidade de São Paulo, São Paulo

21. Owen CB, Coburn S, Castor MJ (2014) Teaching modern object-oriented programming to the blind: an instructor and student experience. In: Proceedings of the 121st ASEE Annual Conference. ASEE

22. Müller K (2012) How to make unified modeling language diagrams accessible for blind students. In: Miesenberger K, KarshmerPetr A, Zagler P (eds). Computers helping people with special needs. Springer, Austria

23. Dell AG, Newton DA, Petroff JG (2016) Assistive technology in the classroom: enhancing the school experiences of students with disabilities 3rd edn. Pearson, New York

24. Loitsch C, Weber G (2012) Viable haptic UML for blind people. In: Miesenberger K, KarshmerPetr A, Zagler P (eds). Computers helping people with special needs. Springer, Austria

25. Brookshire RG (2006) Teaching UML database modeling to visually impaired students. Issues Inf Syst 7(1):98-101

26. McMullen D, Fitzpatrick D (2009) Autonomous access to graphics for visually impaired learners. In: Proceedings of the EdTech 2009 - changing learning futures through technology, ILTA, Ireland. p 41

27. Gilkes AM, Cowens MW, Taylor LA (1996) Electronic refreshable tactile display for braille text and graphics. Google Patents. US Patent 5,580,251

28. Charles PK, Harish V, Swathi M, Deepthi CH (2012) A review on the various techniques used for optical character recognition. Int J Eng Res Appl 2(1):659-662

29. Borodin Y, Bigham JP, Dausch G, Ramakrishnan IV (2010) More than meets the eye: a survey of screen-reader browsing strategies. In: Proceedings of the 2010 International Cross Disciplinary Conference on Web Accessibility (W4A). ACM, Raleigh. p 13

30. Cohen RF, Meacham A, Skaff J (2006) Teaching graphs to visually impaired students using an active auditory interface. ACM SIGCSE Bull 38(1):279-282. ACM

31. Connelly R (2010) Lessons and tools from teaching a blind student. J Comput Sci Coll 25(6):34-39

32. Pansanato LTE, Silva CE, Rodrigues L (2012) Uma experiência de inclusão de estudante cego na educação superior em computação [In Portuguese]. In: Proceedings of the Workshop Sobre Educação em Computação, Curitiba

33. Silva CE, Pansanato LTE, Fabri JA (2010) Ensinando diagramas UML para estudantes cegos [In Portuguese]. In: Proceedings of the 36th Latin American Informatics Conference, Asunción, Paraguay

34. Blenkhorn P, Evans DG (1998) Using speech and touch to enable blind people to access schematic diagrams. J Netw Comput Appl 21(1): 17-29

35. Iglesias R, Casado S, Gutierrez T, Barbero Jl, Avizzano CA, Marcheschi S, Bergamasco M (2004) Computer graphics access for blind people through a haptic and audio virtual environment. In: Proceedings of the 3rd IEEE International Workshop on Haptic, Audio and Visual Environments and Their Applications. IEEE, Ottawa. pp 13-18

36. Lötzsch J (1994) Computer-aided access to tactile graphics for the blind. In: Zagler W, Busby G, Roland W (eds). Computers for handicapped persons. Springer, Austria. pp 575-581

37. Oliveira F, Cowan H, Fang B, Quek F (2010) Enabling multimodal discourse for the blind. In: Proceedings of the International Conference on Multimodal Interfaces and the Workshop on Machine Learning for Multimodal Interaction. ACM, Beijing. p 18
38. Ramloll R, Yu W, Brewster S, Riedel B, Burton M, Dimigen G (2000) Constructing sonified haptic line graphs for the blind student: first steps. In: Proceedings of the Fourth International ACM Conference on Assistive Technologies. ACM, Arlington. pp 17-25

39. Yu W, Brewster S (2003) Evaluation of multimodal graphs for blind people. Univ Access Inf Soc 2(2):105-124

40. King A (2008) Accessible UML. http://www.alasdairking.me.uk/tedub/ index.htm. Accessed 16 Jan 2018

41. King A Accessible UML reference manual. http://access.uoa.gr/manuals/ tedub/Accessible\%20UML\%20Manual.doc. Accessed 16 Jan 2018

42. Cohen RF, Yu R, Meacham A, Skaff J (2005) PLUMB: displaying graphs to the blind using an active auditory interface. In: Proceedings of the 7th International ACM SIGACCESS Conference on Computers and Accessibility. ACM, Baltimore. pp 182-183

43. Kennel AR (1996) Audiograf: a diagram-reader for the blind. In: Proceedings of the 2 nd Annual ACM Conference on Assistive Technologies. ACM, Vancouver. pp 51-56

44. King A, Blenkhorn P, Crombie D, Dijkstra S, Evans G, Wood J (2004) Presenting UML software engineering diagrams to blind people. In: Miesenberger K, Klaus J, Zagler WL, Burger D (eds). Computers helping people with special needs. Lecture Notes in Computer Science. Springer, France. pp 522-529

45. Metatla O, Bryan-Kinns N, Stockman T (2008) Constructing relational diagrams in audio: the multiple perspective hierarchical approach. In: Proceedings of the 10th International ACM SIGACCESS Conference on Computers and Accessibility. ACM. pp 97-104

46. Petrie $H$, Schlieder $C$, Blenkhorn $P$, Evans $G$, King A, O'Neill AM, loannidis GT, Gallagher B, Crombie D, Mager R, et al. (2002) Tedub: a system for presenting and exploring technical drawings for blind people. In: Miesenberger K, KarshmerPetr A, Zagler P (eds). Computers helping people with special needs. Springer, Austria. pp 537-539

47. Vieritz H, Schilberg D, Jeschke S (2014) Access to UML diagrams with the HUTN. In: Automation, communication and cybernetics in science and engineering 2013/2014. Springer, Germany. pp 751-755

48. Grillo FDN, deMattos Fortes RP (2014) Accessible modeling on the web: a case study. Procedia Comput Sci 27:460-470

49. Grillo FDN, de Mattos Fortes RP, Lucrédio D (2012) Towards collaboration between sighted and visually impaired developers in the context of model-driven engineering. In: Joint Proceedings of Co-located Events at the 8th European Conference on Modelling Foundations and Applications (ECMFA 2012), Lyngby. pp 241-251

50. Luque L, Brandão LO, Tori R, Brandão AAF (2014) Are you seeing this? what is available and how can we include blind students in virtual UML learning activities. In: Proceedings of the XXV Brazilian Conference of Informatics in Education, Dourados Vol. 25. pp 204-213

51. Luque L, de Oliveira Brandão L, Tori R, Brandão AAF (2015) On the inclusion of blind people in UML e-learning activities. Braz J Inf Educ 23(02):18

52. Luque L, Brandão LO, Brandão AAF (2016) Model2gether: uma ferramenta de apoio ao ensino e a aprendizagem de modelos por cegos [In Portuguese]. In: Anais Dos Workshops do Congresso Brasileiro de Informática na Educação, Uberlândia Vol. 5. p 257

53. Capovilla D, Mühling A, Hubwieser P (2015) How learning styles in CS can foster inclusion of visually impaired students. In: Proceedings of the 2015 International Conference on Learning and Teaching in Computing and Engineering (LaTiCE). IEEE, Taipei. pp 187-192

54. UFRGS Lista Geral da SBC [In Portuguese]. https://listas.ufrgs.br/mailman/ listinfo/Sbc-l/. Accessed 16 Jan 2018

55. Forum G Cegos Programadores [In Portuguese]. https://groups.google. com/forum/\#!forum/cegos_programadores. Accessed 16 Jan 2018

56. Google Google Docs. https://docs.google.com. Accessed 16 Jan 2018

57. SurveyMonkey. https://pt.surveymonkey.com/. Accessed 16 Jan 2018

58. Buzzi MC, Buzzi M, Leporini B, Mori G, Penichet VMR (2010) Accessing google docs via screen reader. In: Miesenberger K, Klaus J, Zagler WL, Karshmer A (eds). Computers helping people with special needs. Springer, Austria. pp 92-99

59. Mueller J (2008) Accessibility for everybody: understanding the Section 508 accessibility requirements. Apress, USA

60. Consortium WWW, et al. Web content accessibility guidelines (WCAG) 2.0. https://www.w3.org/TR/WCAG20/. Accessed 16 Jan 2018

61. SurveyMonkey. https://help.surveymonkey.com/articles/en_US/kb/508Compliance/. Accessed 16 Jan 2018 
62. Wentz B, Lazar J (2009) Email accessibility and social networking. Online Communities Soc Comput 5621:134-140

63. Wentz B, Lazar J (2011) Usability evaluation of email applications by blind users. J Usability Stud 6(2):75-89

64. QS QS university rankings - Latin America. http://www.topuniversities. com/university-rankings/latin-american-university-rankings/2016. Accessed 16 Jan 2018

65. MEC (2017) Sistemas eletrônico do Ministério da Cultura e Educação [In Portuguese]. http://emec.mec.gov.br/emec/nova. Accessed 16 Jan 2018

66. Education TH Times higher education universities ranking. https://www. timeshighereducation.com/. Accessed 16 Jan 2018

67. Wikipedia Lista de unidades federativas do Brasil por PIB [In Portuguese]. https://pt.wikipedia.org/wiki/ Lista_de_unidades_federativas_do_Brasil_por_PIB. Accessed 16 Jan 2018

68. Metatla O, Bryan-Kinns N, Stockman T, Martin F (2012) Supporting cross-modal collaboration in the workplace. In: Proceedings of the 26th Annual BCS Interaction Specialist Group Conference on People and Computers. British Computer Society, Birmingham. pp 109-118

69. Disability Resource Center - University of Reno. http://www.unr.edu/drc. Accessed 16 Jan 2018

70. Disability Resource Center - University of Kentucky. https://www.uky.edu/ DisabilityResourceCenter/. Accessed 16 Jan 2018

71. Disability Resource Centre - University of Cambridge. http://www. disability.admin.cam.ac.uk/. Accessed 16 Jan 2018

72. MEC - Ministério da Educação Projeto Livros Acessíveis [In Portuguese]. https://goo.gl/Yprw5h. Accessed 16 Jan 2018

73. University of Washington Access Computing. https://www.washington. edu/accesscomputing. Accessed 16 Jan 2018

\section{Submit your manuscript to a SpringerOpen ${ }^{\circ}$ journal and benefit from:}

- Convenient online submission

- Rigorous peer review

- Open access: articles freely available online

- High visibility within the field

- Retaining the copyright to your article

Submit your next manuscript at $\gg$ springeropen.com 